\title{
Appendicectomy, tonsillectomy, and inflammatory bowel disease: a case-control record linkage study
}

\author{
L M Kurina, M J Goldacre, D Yeates, V Seagroatt
}

J Epidemiol Community Health 2002;56:551-554

\begin{abstract}
Study objective: To determine whether appendicectomy and tonsillectomy are associated with ulcerative colitis (UC) or Crohn's disease (CD); and, if so, whether the associations are related to age at operation.

Design: Nested case-control studies using a longitudinal database of linked hospital and death record abstracts.

Setting: Southern England.

Patients: Statistical records of people diagnosed with UC, CD, or a control condition admitted to hospitals in a defined area.

Main results: Appendicectomy under the age of 20 years was associated with a significantly reduced subsequent risk of UC (relative risk $=0.48,95 \%$ confidence interval 0.30 to 0.73 ). The association appeared strongest for appendicectomy between 10 and 14 years of age (relative risk $=0.29,95 \% \mathrm{Cl}$ 0.09 to 0.68 ). Appendicectomy at the age of 20 years and over was associated with an increased subsequent risk of $C D$ (relative risk $=1.92,95 \% \mathrm{Cl} 1.58$ to 2.32 ), largely confined to those people whose $C D$ was diagnosed within a year of appendicectomy. Appendicectomy under 20 years of age, undertaken five years or more before case or control conditions, was suggestively associated with a reduced risk of $\mathrm{CD}$ (relative risk $=0.71,95 \% \mathrm{Cl} 0.47$ to 1.03 ). Prior tonsillectomy was not associated with any increase or decrease of risk of either UC or CD.

Conclusions: Appendicectomy is associated with a reduced risk of UC; and the association is specific to young age groups when the population risk of appendicitis is itself highest. The increased risk of CD after appendicectomy, at short time intervals between the two, is probably attributable to the misdiagnosis of $C D$ as appendicitis.
\end{abstract}

See end of article for authors' affiliations

23 November 2001

$\mathrm{T}$ he causes of ulcerative colitis (UC) and Crohn's disease (CD) are still largely unknown. There is emerging evidence that appendicectomy is associated with a reduced risk of UC, though not of $\mathrm{CD}^{1-14}$ Results of a laboratory study suggested that appendicectomy itself protected against inflammatory bowel disease (IBD). ${ }^{15}$ However, recent epidemiological evidence suggests that it may be appendicitis rather than appendicectomy that shows the inverse relation with UC. ${ }^{13} 16$ The risk reduction seems most prominent in those who undergo appendicectomy under the age of $20 .{ }^{15}$

Tonsillectomy, like appendicectomy, entails the removal of gut associated lymphoid tissue. Studies have consistently shown no association between tonsillectomy and UC. ${ }^{25} 9_{11}^{1317} 18$ However, there is some evidence for a positive association between tonsillectomy and CD, particularly in some subgroups of patients. ${ }^{13141718}$

We have used population based data from a health region in the southern part of England to determine whether appendicectomy and tonsillectomy are associated with UC or CD in this population, and, if so, whether the associations are related to age at, and time from, operation.

\section{METHODS}

The Oxford Record Linkage Study (ORLS) database includes statistical abstracts of records of general hospital admissions (including day cases) and death certificates in a defined population in southern England. ${ }^{19}$ The area covered had a population of about 350000 people in 1963; it expanded to cover 1.9 million from 1975 and 2.5 million (all eight health districts in the former Oxford health region) from 1987. All diagnostic data were coded by trained coders using the International Classification of Diseases ( see appendix for the codes used for the case and exposure conditions in this study). The statistical abstracts for each person have been linked together from l January 1963 to 31 March 1999 and anonymised (ORLS file $5 \mathrm{vlc}$ ).

The method of analysis was a series of nested case-control studies, described in detail elsewhere. ${ }^{20}{ }^{21}$ The cases comprised all those people with UC $(n=7273)$ or $C D(n=5023)$ recorded on a hospital admission record or death certificate. The controls for the analyses were people who had been admitted to hospital for any one of a wide range of other medical or surgical conditions (see appendix). Approximately 750000 persons were included as controls for each comparison. The prior "exposure" events, recorded as an operation on a hospital admission record before the first admission for the case condition, were appendicectomy (subsequently divided into appendicectomy with a diagnosis of appendicitis and appendicectomy without a diagnosis of appendicitis) and tonsillectomy. Selection procedures for dealing with multiple diagnoses per admission and multiple admissions per person were as described elsewhere. ${ }^{20}$

Expected numbers of exposed people among the cases were calculated as follows. We first determined the occurrence of the exposure condition in the control group, calculating rates of exposure stratified by age in five year bands, sex, district of residence, and year of occurrence. These stratified rates were then applied to the case population to generate an expected number of cases with the exposure condition. The observed number of case individuals with the exposure condition was

Abbreviations: UC, ulcerative colitis; $C D, C$ rohn's disease; IBD, inflammatory bowel disease 
Table 1 Age and sex distributions of the cases and controls

\begin{tabular}{llll}
\hline & $\begin{array}{l}\text { Patients with } \\
\text { ulcerative } \\
\text { colitis } \mathrm{n}(\%)\end{array}$ & $\begin{array}{l}\text { Patients with } \\
\text { Crohn's } \\
\text { disease } \mathrm{n}(\%)\end{array}$ & Controls $\mathrm{n}(\%)$ \\
\hline $\begin{array}{l}\text { Total } \\
\text { Sex }\end{array}$ & $7273(100)$ & $5023(100)$ & $749322(100)$ \\
$\quad \begin{array}{l}\text { Male } \\
\text { Female }\end{array}$ & $3533(49)$ & $2034(40)$ & $361632(48)$ \\
$\begin{array}{c}\text { Age (y) } \\
<20\end{array}$ & $3740(51)$ & $2989(60)$ & $387690(52)$ \\
$20-49$ & $326(4)$ & $445(9)$ & $189648(25)$ \\
$50+$ & $3474(48)$ & $2842(57)$ & $331198(44)$ \\
& $3473(48)$ & $1736(34)$ & $228476(31)$ \\
\hline
\end{tabular}

divided by the expected number to yield an estimate of the relative risk. A Poisson distribution was assumed for the observed values, and confidence intervals for the relative risks were calculated accordingly.

\section{RESULTS}

The age and sex distributions of the cases and controls are given in table 1. A greater percentage of cases than controls were 50 years of age or older; but we stratified for age in the analyses that follow.

\section{Ulcerative colitis}

Appendicectomy in people under the age of 20 years (table 2), and particularly in those between 10 and 14 years of age (table 3 ), was associated with a significantly reduced risk of UC.

It seems from our data that the reduction in risk of UC may be specific to those people whose appendicectomies were associated with a diagnosis of appendicitis (table 3). However, numbers in the subgroups were small and, for people under 20 years of age at appendicectomy, the difference between those with and without appendicitis was not statistically significant.

There was no evidence that appendicectomy at older ages protected against UC (table 2). If anything, UC in older people was associated with a slightly higher appendicectomy rate than that in controls, particularly at a short time interval between case or control event and appendicectomy.

\section{Crohn's disease}

Prior appendicectomy was associated with a significantly increased risk of CD (table 2). Analysis by time interval between operation and case condition showed that the association between prior appendicectomy and CD was strongest in the year after the appendicectomy. In people who underwent appendicectomy under 20 years of age, the relative risk did not significantly exceed 1.0 at time intervals longer than one year between appendicectomy and CD. In fact, when five or more years separated the events, there was a reduction in risk (though non-significant) of CD (table 2).

\section{Tonsillectomy before UC and CD}

Prior tonsillectomy was not associated with any increase or decrease of risk of either UC or CD (table 2).

\section{DISCUSSION}

The ORLS includes hospitalised patients only and it does not follow up those who migrate outside the area. The implications of these limitations have been discussed in some detail elsewhere ${ }^{2021}$; but while the absolute values of disease occurrence (and operation rates) are underestimated, the relative risks we quote should be valid measures of association.

Our prior hypotheses, generated by findings in an earlier study, ${ }^{1}$ were that appendicectomy reduces the risk of UC; that the reduction is restricted to appendicectomy before 20 years of age; and that the risk reduction is greatest in people who undergo appendicectomy for appendicitis rather than for conditions that mimic it. Our results confirm that prior appendicectomy reduces the risk of UC and that the risk reduction is limited to people who are relatively young at the time of appendicectomy. ${ }^{15}$ The strongest reduction in risk of UC was associated with appendicectomy between the ages of 10 and 14 years, which is the peak age, at least in this population, for acute appendicitis. ${ }^{22}$ This adds some strength to the suggestion in our data, and that of others, ${ }^{13}$ that the inverse association

Table 2 Prior appendicectomy or tonsillectomy in people with ulcerative colitis or Crohn's disease: observed (Obs) and expected (Exp) numbers of people with each operation and ratios of observed to expected $(\mathrm{O} / \mathrm{E})$, with their $95 \%$ confidence intervals (CI)

\begin{tabular}{|c|c|c|c|c|c|c|c|c|c|c|}
\hline \multirow[b]{2}{*}{ Operation } & \multirow{2}{*}{$\begin{array}{l}\text { Age in years at } \\
\text { operation }\end{array}$} & \multirow{2}{*}{$\begin{array}{l}\text { Years from } \\
\text { operation }\end{array}$} & \multicolumn{4}{|c|}{ Ulcerative colitis } & \multicolumn{4}{|c|}{ Crohn's disease } \\
\hline & & & Obs & Exp & O/E & $95 \% \mathrm{Cl}$ & Obs & Exp & O/E & $95 \% \mathrm{Cl}$ \\
\hline \multirow[t]{9}{*}{ Appendicectomy } & $<20$ & $<1$ & 1 & 1.6 & 0.63 & 0 to 3.59 & 14 & 2.0 & 7.16 & 3.90 to 12.05 \\
\hline & & $1-4$ & 4 & 7.9 & 0.51 & 0.13 to 1.31 & 12 & 11.2 & 1.07 & 0.55 to 1.87 \\
\hline & & $\geqslant 5$ & 17 & 36.4 & 0.47 & 0.27 to 0.75 & 28 & 39.5 & 0.71 & 0.47 to 1.03 \\
\hline & & All & 22 & 45.6 & 0.48 & 0.30 to 0.73 & 54 & 53.2 & 1.02 & 0.76 to 1.33 \\
\hline & $\geqslant 20$ & $<1$ & 11 & 6.2 & 1.78 & 0.88 to 3.20 & 40 & 5.5 & 7.31 & 5.22 to 9.96 \\
\hline & & $1-4$ & 24 & 21.6 & 1.11 & 0.71 to 1.66 & 36 & 17.0 & 2.12 & 1.48 to 2.93 \\
\hline & & $\geqslant 5$ & 62 & 52.5 & 1.18 & 0.90 to 1.51 & 32 & 33.5 & 0.95 & 0.65 to 1.35 \\
\hline & & All & 97 & 80.5 & 1.21 & 0.98 to 1.47 & 108 & 56.2 & 1.92 & 1.58 to 2.32 \\
\hline & All ages & All & 119 & 125.9 & 0.95 & 0.78 to 1.13 & 162 & 107.6 & 1.51 & 1.28 to 1.76 \\
\hline \multirow[t]{9}{*}{ Tonsillectomy } & $<20$ & $<1$ & 2 & 1.5 & 1.35 & 0.13 to 4.96 & 1 & 1.9 & 0.53 & 0 to 3.01 \\
\hline & & $1-4$ & 6 & 6.9 & 0.87 & 0.31 to 1.90 & 17 & 11.2 & 1.51 & 0.88 to 2.43 \\
\hline & & $\geqslant 5$ & 75 & 84.1 & 0.89 & 0.70 to 1.12 & 120 & 105.5 & 1.14 & 0.94 to 1.36 \\
\hline & & All & 83 & 92.9 & 0.89 & 0.71 to 1.11 & 138 & 119.2 & 1.16 & 0.97 to 1.37 \\
\hline & $\geqslant 20$ & $<1$ & 3 & 2.9 & 1.05 & 0.20 to 3.11 & 1 & 2.8 & 0.36 & 0 to 2.06 \\
\hline & & $1-4$ & 10 & 9.7 & 1.03 & 0.49 to 1.90 & 5 & 9.1 & 0.55 & 0.17 to 1.29 \\
\hline & & $\geqslant 5$ & 19 & 19.2 & 0.99 & 0.59 to 1.54 & 15 & 14.7 & 1.02 & 0.57 to 1.69 \\
\hline & & All & 32 & 31.1 & 1.03 & 0.70 to 1.45 & 21 & 26.4 & 0.80 & 0.49 to 1.22 \\
\hline & All ages & All & 115 & 124.2 & 0.93 & 0.76 to 1.11 & 159 & 144.9 & 1.10 & 0.93 to 1.28 \\
\hline
\end{tabular}


Table 3 Appendicectomy before ulcerative colitis showing data in five year age groups at time of appendicectomy, and showing data for people who underwent appendicectomy with or without a record of appendicitis: observed (Obs) and expected (Exp) numbers of people in each subgroup, and the ratios of observed to expected $(\mathrm{O} / \mathrm{E})$ with their $95 \%$ confidence intervals $(\mathrm{Cl})$

\begin{tabular}{|c|c|c|c|c|c|}
\hline Operation & Age $(y)$ & Obs & Exp & O/E & $95 \% \mathrm{Cl}$ \\
\hline All appendicectomy & $\begin{array}{l}<5 \\
5-9 \\
10-14 \\
15-19 \\
20-24 \\
25-29 \\
30-34 \\
\geqslant 35\end{array}$ & $\begin{array}{l}0 \\
4 \\
5 \\
13 \\
14 \\
15 \\
13 \\
55\end{array}$ & $\begin{array}{l}0.5 \\
5.8 \\
17.3 \\
22.1 \\
16.7 \\
12.9 \\
10.3 \\
40.8\end{array}$ & $\begin{array}{l}0 \\
0.69 \\
0.29 \\
0.59 \\
0.84 \\
1.17 \\
1.26 \\
1.35\end{array}$ & $\begin{array}{l}0 \text { to } 7.94 \\
0.18 \text { to } 1.79 \\
0.09 \text { to } 0.68 \\
0.31 \text { to } 1.01 \\
0.46 \text { to } 1.41 \\
0.65 \text { to } 1.93 \\
0.67 \text { to } 2.17 \\
1.02 \text { to } 1.76\end{array}$ \\
\hline $\begin{array}{l}\text { Appendicectomy with } \\
\text { appendicitis }\end{array}$ & $\begin{array}{l}<20 \\
\geqslant 20\end{array}$ & $\begin{array}{l}15 \\
67\end{array}$ & $\begin{array}{l}35.3 \\
58.2\end{array}$ & $\begin{array}{l}0.43 \\
1.15\end{array}$ & $\begin{array}{l}0.24 \text { to } 0.70 \\
0.89 \text { to } 1.46\end{array}$ \\
\hline $\begin{array}{l}\text { Appendicectomy without } \\
\text { appendicitis }\end{array}$ & $\begin{array}{l}<20 \\
\geqslant 20\end{array}$ & $\begin{array}{l}7 \\
30\end{array}$ & $\begin{array}{l}10.4 \\
22.4\end{array}$ & $\begin{array}{l}0.67 \\
1.34\end{array}$ & $\begin{array}{l}0.27 \text { to } 1.39 \\
0.90 \text { to } 1.92\end{array}$ \\
\hline
\end{tabular}

\section{Key points}

- The aetiology of inflammatory bowel disease is largely unknown and therefore any clues about aetiological factors are of interest.

- This study confirms a significantly reduced risk of ulcerative colitis in people who have undergone appendicectomy.

- The reduced risk was specific to appendicectomy in childhood and young adulthood.

- An increased risk of Crohn's disease was found after appendicectomy and was probably attributable to misdiagnosis of the former appendicitis.

- Tonsillectomy was not associated with any change of risk of ulcerative colitis or Crohn's disease.

between appendicectomy and UC may be attributable to an inverse association between appendicitis and UC. No association was found in our study between tonsillectomy and either IBD, giving additional weight to the specificity of the inverse relation between appendicectomy and UC.

A Danish registry study, published after the submission of our paper, found no significant reduction in risk of UC after appendicectomy. ${ }^{23}$ The overall risk estimate for appendicectomy at all ages was 0.87 (95\% CI 0.69 to 1.07$)$. The relative risk was lower in those under 20 years of age (relative risk $=0.74,95 \%$ CI 0.47 to 1.11 ). Though not significant, this risk estimate is consistent with our results.

Two studies have shown a positive association between appendicectomy and CD. ${ }^{77}$ The excess risk was explained as the result either of prophylactic appendicectomies done during the course of CD related laparotomies or of misdiagnosis of CD as appendicitis. It is well recognised clinically that some patients with CD "present with the clinical features of acute appendicitis". ${ }^{24}$ Our data also show a positive association between prior appendicectomy and CD. The relative risk of CD is particularly high over very short time intervals (less than one year) after appendicectomy (table 2). The most probable explanation for these results is that, in these patients, CD is first misdiagnosed as appendicitis. In fact, our data suggest that appendicectomy rates may be low in young people at long time intervals before CD. It is conceivable that a real inverse association in young people is masked by the fact that CD sometimes mimics appendicitis.

If appendicectomy is inversely related to UC, what might the mechanism be? One hypothesis suggests that appendicitis and ulcerative colitis may be divergent responses to childhood hygiene. For example, Ekbom ${ }^{16}$ argued that the decline in the incidence of appendicitis over the past 10 years in Sweden could be a result of the increased use of day care centres for very young children, and, presumably, the consequent increase in exposure to pathogens early in life. Citing evidence of an association between early infectious events and IBD, ${ }^{27}$ Ekbom implied that these events might shape the immune system in such a way that the risk of appendicitis is decreased but the risk of UC increased. ${ }^{16}$ Conversely, the steady decline in appendicitis observed in developed countries over the past few decades could be interpreted as the result of further improvements in hygiene protecting against exogenous pathogens. ${ }^{25} 28$ The same improvements in hygiene that protect against appendicitis may predispose susceptible people to UC. For example, given that UC has an autoimmune component, reduced exposure to pathogens early in life might result in an inappropriate immune response to a triggering antigen in late adolescence or early adulthood. However, although two studies have shown a positive relation between early domestic hygiene and $\mathrm{CD}_{,}{ }^{56}$ this relation has not been observed for UC. ${ }^{5}$

One of the few established risk factors for IBD is smoking. Smoking protects against UC and predisposes to CD. ${ }^{29}{ }^{30} \mathrm{~A}$ limitation of the ORLS dataset is the absence of information on lifestyle variables, including smoking habits. Confounding could be an important consideration if smoking is also associated with appendicitis. However, a recent case-control study showed no relation between having ever smoked and having had an appendicectomy. ${ }^{5}$ Furthermore, there is evidence from other studies that the inverse relation between appendicectomy and UC remains after adjustment for smoking status. $^{41112}$ Smoke inhalation early in life may be an important consideration; two recent cohort studies reported an increased risk of appendicectomy among the children of parents who smoke. ${ }^{26}{ }^{32}$ If these children are more likely to smoke themselves, this could, at least in part, account for the dissociation between appendicitis and UC.

In summary, we confirm that there is an inverse association between appendicectomy and UC and that it is specific to people who have appendicectomies in childhood and young adulthood. We confirm that tonsillectomy is not associated with the risk of UC or CD.

\section{ACKNOWLEDGEMENTS}

We thank Leicester Gill, Glenys Bettley and Myfanwy Griffith for building the linked files. 
APPENDIX

The International Classification of Diseases (ICD) diagnosis and Office of Population Censuses and Surveys (OPCS) operation codes used for the case and exposure conditions in this study were as follows:

\begin{tabular}{lllll}
\hline Diagnoses & ICD 7 & ICD 8 & ICD 9 & ICD 10 \\
\hline $\begin{array}{l}\text { Case conditions } \\
\text { Ulcerative colitis } \\
\text { Crohn's disease }\end{array}$ & 572.2 & 563.1 & 556 & K51 \\
$\begin{array}{llll}\text { Exposures } \\
\text { Appendicitis }\end{array}$ & $550-552$ & $540-542$ & $540-542$ & K50 \\
\hline Operations & OPCS 1 & OPCS 2 & OPCS 3 & K35-K37 \\
\hline $\begin{array}{l}\text { Appendicectomy } \\
\text { Tonsillectomy }\end{array}$ & 441 & $441,443,444$ & $441-444$ & OPCS 4 \\
\hline
\end{tabular}

The control conditions used in this study were as follows, using the terminology of ICD9 and the OPCS Classification of Surgical Operations, Third Revision: sebaceous cyst; disorders of tooth development and eruption; diseases of hard tissues of teeth; deflected nasal septum; nasal polyps; varicose veins of lower extremities; haemorrhoids; acute respiratory infections; strabismus; cataract; inguinal hernia; diseases of nail; internal derangement of knee; bunion; contraceptive management; dilatation of cervix and curettage of uterus; head injuries; fracture of upper limb and lower limb; disloations, sprains, and strains; superficial injury and contusion; total hip replacement; total knee replacement.

\section{Authors' affiliations}

L M Kurina, M J Goldacre, D Yeates, V Seagroatt, Unit of

Health-Care Epidemiology, Department of Public Health, University of Oxford, Institute of Health Sciences, Oxford, UK

Funding: The Unit of Health-Care Epidemiology and the Oxford Record Linkage Study are funded by the South East Regional Office of the National Health Service Executive. LK was funded by an Alfred P Sloan Postdoctoral Fellowship in the manuscript revision stage.

Conflicts of interest: none.

\section{REFERENCES}

1 Andersson RE, Olaison G, Tysk C, et al. Appendectomy and protection against ulcerative colitis. N Engl J Med 2001;344:808-14

2 Breslin NP, McDonnell C, O'Morain C. Surgical and smoking history in inflammatory bowel disease: a case-control study. Inflamm Bowel Dis 1997:3:1-5.

3 Derby LE, Jick H. Appendectomy protects against ulcerative colitis. Epidemiology 1998;9:205-7.

4 Dijkstra B, Bagshaw PF, Frizelle FA. Protective effect of appendectomy on the development of ulcerative colitis: matched, case-control study. Dis Colon Rectum 1999:42:334-6.

5 Duggan AE, Usmani I, Neal KR, et al. Appendicectomy, childhood hygiene, Helicobacter pylori status, and risk of inflammatory bowel disease: a case control study. Gut 1998;43:494-8.

6 Gent $\mathbf{A E}$, Hellier MD, Grace RH, et al. Inflammatory bowel disease and domestic hygiene in infancy. Lancet 1994;343:766-7.

7 Gilat T, Hacohen D, Lilos P, et al. Childhood factors in ulcerative colitis and Crohn's disease. An international cooperative study. Scand J Gastroenterol 1987;22:1009-24.

8 Kubba AK, Price RF, Smith G, et al. Appendicectomy and ulcerative colitis. J R Coll Surg Edinb 1998;43:244-5.

9 Minocha A, Raczkowski CA. Role of appendectomy and tonsillectomy in pathogenesis of ulcerative colitis. Dig Dis Sci 1997;42:1567-9.

10 O'Gorman P, Bennett D, Kavanagh E, et al. MALTectomy (appendectomy/tonsillectomy) does not influence the occurrence or mode of presentation of adult celiac disease. Am J Gastroenterol 1996;91:723-5

11 Parrello T, Pavia M, Angelillo IF, et al. Appendectomy is an independent protective factor for ulcerative colitis: results of a multicentre case control study. Ital J Gastroenterol Hepatol 1997:29:208-13.

12 Russel MG, Dorant E, Brummer RIM, et al. Appendectomy and the risk of developing ulcerative colitis or Crohn's disease: results of a large case-control study. Gastroenterology 1997;1 13:377-82

13 Smithson JE, Radford-Smith G, Jewell GP. Appendectomy and tonsillectomy in patients with inflammatory bowel disease. J Clin Gastroenterol 1995;21:283-6.
14 Wurzelmann JI, Lyles CM, Sandler RS. Childhood infections and the risk of inflammatory bowel disease. Dig Dis Sci 1994;39:555-60.

15 Mizoguchi A, Mizoguchi E, Chiba C, et al. Role of appendix in the development of inflammatory bowel disease in TCR-a mutant mice. J Exp Med 1996; 184:707-15

16 Ekbom A. Appendicectomy and childhood hygiene: different sides of the same coin? Gut 1998:43:451.

17 Koutroubakis IE, Vlachonikolis IG, Kapsoritakis A, et al. Appendectomy, tonsillectomy, and risk of inflammatory bowel disease case-controlled study in Crete. Dis Colon Rectum 1999;42:225-30.

18 Maté-Jimenez J, Correa-Estan JA, Perez-Miranda M, et al. Tonsillectomy and inflammatory bowel disease location. Eur J Gastroenterol Hepatol 1996;8: 1185-8.

19 Goldacre MJ, Simmons H, Henderson J, et al. Trends in episode based and person based rates of admission to hospital in the Oxford record linkage study area. BM 1988;296:583-5.

20 Goldacre M, Kurina L, Yeates D, et al. Use of large medical databases to study associations between diseases. QJM 2000;93:669-75.

21 Kurina LM, Goldacre M, Yeates D, et al. Depression and anxiety in people with inflammatory bowel disease. J Epidemiol Community Health 2001;55:716-20

22 Primatesta P, Goldacre M. Appendicectomy for acute appendicitis and for other conditions: an epidemiological study. Int J Epidemiol 1994; 23: 155-60.

23 Frisch $M$, Johansen $C$, Mellemkiær L, et al. Appendectomy and subsequent risk of inflammatory bowel diseases. Surgery $2001 ; 130: 36-43$

24 Jewell D. Crohn's disease. In: Weatherall DJ, Ledingham JGG, Warrell DA, eds. Oxford textbook of medicine. 3rd ed. Oxford: Oxford University Press, 1996:1938.

25 Barker DJP, Morris J. Acute appendicitis, bathrooms, and diet in Britain and Ireland. BM 1988:296:953-5.

26 Montgomery SM, Pounder RE, Wakefield AJ. Smoking in adults and passive smoking in children are associated with acute appendicitis. Lancet 1999;353:379.

27 Ekbom A, Adami HO, Helmick CG, et al. Perinatal risk factors for inflammatory bowel disease: a case-control study. Am J Epidemiol 1990;132:1111-19.

28 Barker DJP, Osmond C, Golding J, et al. Acute appendicitis and bathrooms in three samples of British children. BMV 1988;296:956-8.

29 Thomas GAO, Rhodes J, Green JT. Inflammatory bowel disease and smoking-a review. Am J Gastroenterol 1998;93:144-9.

30 Vessey M, Jewell D, Smith A, et al. Chronic inflammatory bowel disease, cigarette smoking, and use of oral contraceptives: findings in a large cohort study of women of childbearing age. BMU 1986;292:1101-3.

31 Rhodes J, Thomas GAO. Smoking: good or bad for inflammatory bowel disease? Gastroenterology 1994;106:807-10.

32 Rutland BK, Strachan DP. Smoking and acute appendicitis. Lancet 1999;353:1712. 